\title{
El proceso de la religión en Lutero, Spinoza y Bayle
}

UESTRA época sufre un profundo desencanto del hombre
con Dios. Afirmaciones de intelectuales como la de Solye-
nitzin con respecto al reavivamiento de la religiosidad rusa, o la
de Kolakowsky quien ve en la identidad religiosa y en el naciona-
lismo los factores de desintegración del totalitarismo, o la de Bell
quien reconoce, desde un punto de vista sociológico, un resurgi-
miento religioso íntimamente ligado a un desgaste de las ideolo-
gías; o testimonios como el de los grupos carismáticos en los
Estados Unidos, o el de la madre Teresa de Calcuta, no cabe
duda que son significativos. Sin embargo, el mismo hecho de ser
fácilmente identificables, porque si bien son voces autorizadas
no dejan de ser voces aisladas, confirma lo que parece obvio: el
olvido o la ausencia de Dios. Este olvido, no gratuito ni circuns-
tancial, hinca sus raíces muy atrás en el tiempo y su explicación
está lejos de ser simple. Una de las causas, y no la menos
importante, se debe a un lento proceso de naturalización de la
religión que halló una expresión muy clara en los siglos XVI y
XVII.

El siglo XVI europeo" sirvió de marco histórico para la culminación del renacimiento y el origen del protestantismo. Más que ruptura, existió entre ambos movimientos culturales una relación de continuidad, pues la exaltación del paganismo grecorromano que nació en Italia y se extendió por Alemania, Francia e Inglaterra explicó, entre otras razones, la misma expansión del protestantismo en esos países. Ambos guardaron al menos dos puntos en común: la afirmación de un "humanismo antropocéntrico" a costa de un "humanismo teocéntrico" y, como resultado de tal afirmación, un desprecio por el pensamiento y en general por la cultura medievales. Así, por ejemplo, pudieron enfrentarse Lutero y Erasmo en torno a un tema clásico como el 
del libre albedrío, pero ambos, al fin, fueron hijos de una época en donde los valores humanos ya no se juzgaban desde la perspectiva divina, sino a partir de la misma naturaleza humana, ya fuese con un gran pesimismo o con un optimismo sin límites.

Con todo, los antecedentes renacentistas no explican en su totalidad el origen de la revolución protestante. Al lado de ellos habría que colocar la influencia de la escolástica decadente que, en el plano teológico, tomó como representante más destacado a Guillermo de Occam y, en el plano político, a su discípulo Marsilio de Padua; la influencia de la teología mística alemana con Eckart y su exaltación de la interioridad volitiva del ser humano en un movimiento ascético de ascenso a la divinidad; $y$, al lado de estos planteamientos teóricos, todo un conjunto de hechos importanes como lo fueron el advenimiento de la burguesía con una nueva estructuración de la actividad económica; los grandes problemas políticos suscitados por la relación iglesiaestado que culminaron en el cisma de Occidente y, por último, un relajamiento de costumbres ligado al rompimiento de una tradición de siglos. Todo esto se tradujo en un divorcio paulatino entre la vida natural y la vida sobrenatural que se hizo manifiesto en el problema de razón y fe, libertad y gracia, mundo e iglesia.

El siglo XVI preparó al XVII. Si de Italia el humanismo renacentista se extendió hasta Inglaterra llevando en su corriente toda una visión antropocéntrica reafirmada por el protestantismo, fue en este país donde hizo su aparición el iluminismo cuyos antecedentes en materia de religión deben buscarse en Herberto de Cherbury. Las obras de los ingleses se introdujeron en el continente a través de Holanda y aquí, precisamente con Spinoza, se logró la primera gran síntesis entre los principios racionalistas y algunas tèsis sobre religión natural inspirados en el deísmo insular. La segunda síntesis corrió a cargo de uno de los principales iniciadores del movimiento ilustrado, Pierre Bayle, quien tomando los supuestos del racionalismo y del deísmo encontró una integración final en el protestantismo.

Considerado lo anterior, el objeto de este escrito tiene un doble propósito: primero, hacer explícita la idea de que a partir de Lutero, Spinoza y Bayle se sientan las bases para un tratamiento del hecho religioso como algo autónomo, no inscrito ya en el ámbito de la metafísica o de la teología como era considerado en la filosofía clásica y medieval; segundo, mostrar, 
tal como señalamos más arriba, que una de las razones que explica nuestro actual olvido de Dios tiene sus orígenes en un proceso de naturalización de la religión. En efecto, en los años que van desde Lutero hasta Bayle se operó un proceso paulatino de naturalización que, como esperamos mostrar, comenzó por el enjuiciamiento de la actitud religiosa del hombre para concluir con el cuestionamiento de la existencia misma de Dios. Esta idea será nuestro hilo conductor y para comprender su alcance es necesario decir, aunque sea brevemente, qué sentido daremos al término religión, cómo lo definiremos para, luego, aplicarlo a dicho proceso.

Entendemos la religión desde tres puntos de vista distintos: el ontológico, el gnoseológico y el moral. ${ }^{1}$ Desde el primer punto de vista se intenta encontrar el fundamento último que explique la actividad religiosa. Pensamos que tal fundamento consiste en la religación que tiene todo ente por el hecho de ser creado por Dios; religión que no se refiere únicamente a la constitución interna del ente sino también a su mismo obrar, es decir, tanto en su aspecto estático como en su aspecto dinámico. En esta primera etapa, el hombre se estudia junto con los demás entes como religado a un Ser absoluto.

Desde el punto de vista gnoseológico se trata de encontrar el fundamento que explique nuestro acceso a Dios. Esta segunda etapa se distingue claramente de la anterior pues una cosa es estar religado a Dios y otra cosa es tomar conciencia de tal religación. Esta conciencia en la historia de la filosofía de la. religión no se operó sólo por vía intelectual; los filósofos también acudieron a la vía volitiva y a la vía sentimental.

La tercera etapa es la moral y consiste en la actitud que tiene el hombre al tomar conciencia de su religación ontológica. Es una etapa donde, en sentido estricto, hace su aparición la religión, y es aquí también donde adquiere carta de ciudadanía el ateísmo. Es imposible que surja éste en las dos primeras fases, a menos que se deje de ser ente y ente racional. Puede apreciarse, de paso, la diferencia que existe entre esta etapa y la anterior, pues es factible que existan personas que tomen conciencia de la existencia de Dios y sin embargo, no manifiesten alguna actividad cultural hacia El.

1 Tomarnos el término "moral" en un sentido amplio, como el ámbito que abarca toda actividad humana en tanto ésta se manifiesta, en mayor o menor medida, consciente y libremente. 
Así llegamos a la definición de religión. La religión es un movimiento del hombre que dice "orden a Dios" según la definición clásica de Santo Tomás ${ }^{2}$, entendiendo por orden, en sentido amplio, las tres etapas antes señaladas, y en sentido estricto el culto del hombre a Dios. La religión, entonces, versa sobre lo relativo al culto que supone la sumisión a Dios a través de actos internos de adoración como la oración, o actos externos como la veneración de imágenes que, como representaciones sensibles, nos conducen a Dios. En otras palabras, el objeto formal de la religión consiste en "dar a Dios el culto debido". ${ }^{3}$

Definida la religión y considerada en sus tres etapas desde un punto de vista tomista, el proceso histórico de naturalización no comenzó por criticar la religación ontológica con Dios sino que, como veremos, comenzó por cuestionar la actividad cultural del hombre hacia Dios con el protestantismo; luego la conciencia de nuestra religación con el racionalismo y el deísmo; y, por último, la religación ontológica con el escepticismo ateo.

\section{Lutero y el humanismo protestante}

La doctrina de Lutero sobre la religión se entiende desde una perspectiva práctica. Su intención se halla encaminada a la búsqueda de la felicidad y a la salvación del individuo por encima de cualquier discernimiento de tipo racional o teórico. Desde este punto de vista es notoria la deuda que contrae con toda la tradición platónico-agustiniana que lleva el sello del ascetismo volitivo y de la exaltación de Dios a costa de la disminución ontológica de la criatura.

Para introducirnos a su pensamiento comenzaremos por citar tres textos escogidos de obras diversas:

"Es necesario saber que no hay buenas obras fuera de las ordenadas por Dios, como tampoco hay malas obras excepto las prohibidas por él. En consecuencia, quien quiera conocer buenas obras y realizarlas, sólo necesita conocer los mandamientos de Dios (...). De manera que debemos aprender a distinguir las

${ }^{2}$ Suma Teológica, II-II, p. 81, a 1.

3 lbid., a. 5. Para un desarrollo de la tesis tomista en torno a la religión véase mi artículo "La religión según Santo Tomás de Aquino", Revista de Filosofia, UIA, 1983, Nos. 47-48. 
buenas obras por los mandamientos divinos, y no por la apariencia, grandeza o cantidad de las obras en sí, ni tampoco por el arbitrio de los hombres y las leyes y costumbres humanas, tal como vemos ha sucedido y aún sigue sucediendo, porque somos ciegos y despreciamos en mucho los mandamientos de Dios". ${ }^{4}$

El acento de este texto está puesto en el conocimiento de las buenas obras a través de los mandamientos. Pero es cierto que una cosa es el conocimiento de los mandamientos y otra su realización:

"Los mandamientos nos indican y ordenan toda clase de buenas obras, pero con eso no están ya cumplidas: porque enseñan rectamente, pero no auxilian; instruyen acerca de lo que es preciso hacer, pero no expenden la fuerza necesaria para realizarlas. O sea, los mandamientos han sido promulgados únicamente para que el hombre se convenza por ellos de la imposibilidad de obrar bien y aprenda a reconocerse y a desconfiar de sí mismo".

O puesto en otros términos:

"Pero el objeto esencial de la ley, o sea, su poder consiste en revelar la existencia del pecado original con todos sus frutos y consecuencias, demostrando al hombre la profundísima caída de su naturaleza y qué tan corrompida está". 6

De los tres textos se desprende una idea clara: la ley es dada por Dios para que, al ser conocida por el hombre, reconozca la imposibilidad de obrar bien, desconfíe de sí mismo y descubra la fuente de tal imposibilidad en el pecado original. Nada más concluyente para poder tachar esta doctrina de pesimista. Sin embargo, antes de aventurar un juicio de esta índole debemos analizar y aclarar esta afirmación preguntándonos primero, ¿cuál es el trasfondo histórico-filosófico que la anima? y segundo, ¿cuál es el aporte original de Lutero?

Sin duđa, Lutero es deudor de la tradición platónico-agustiniana pero, sobre todo, de la escolástica tardía, y muy

4 Sermón sobre las buenas obras, Antologia, PEN. Barcelona, 1968, Primera Parte, l.

5. La libertad cristiana, Casa Unida de Publicaciones, México, 1946, Cap. VIII.

- Los artículos de Esmalcalda, en Páginas Escogidas, La Aurora, Buenos Aires, 1961, Tercera Parte, La Ley. 
especialmente de Guillermo de Occam. El hombre, pensaba Occam, en tanto criatura, depende enteramente de Dios, se halla religado a El y esta religación ontológica se expresa en forma de obligación moral. Sólo el Absolutum, como lo expresa la palabra, no depende de algo o alguien y, por lo mismo, es enteramente libre, omnipotente, des-obligado. Consecuente con ello, Occam se ve impelido a reducir tudo lo creado a una radical contingencia. Esto, unido al nominalismo que le permite rechazar toda idea universal - géneros, especies - en la mente divina y aceptar, únicamente, a los individuos, le lleva a negar la ley natural y, con ella, toda posible norma objetiva de moralidad?

Al ser así, piensa Occam, la moralidad en los actos humanos ya no les es intrínseca, sino que debe buscarse y fundamentarse en la voluntad divina, en la libre decisión divina. Por esto es comprensible en su ética que un acto sea malo no porque sea intrínsecamente malo, es decir, porque no se adecúe a la recta razón y a la ley natural, sino porque Dios, en su absoluta libertad, decidió prohibir ese acto. Así, el robar es malo porque Dios lo prohibió, como ayudar al necesitado es bueno porque: Dios lo ordenó. Ahora bien, ¿cómo puede el hombre llegar a conocer las prohibiciones y ordenamientos que dependen absolutamente de la decisión divina, si se le cierra el acceso a una ley natural porque no existe? Occam responde: a través de la Revelación. Esto quiere decir que para Occam la ética no puede ser sino una ética revelada.

$Y$ es que el problema que se le presenta a Occam y que lo conduce a un dilema en su posición filosófica, es el de la incompatibilidad entre la omnipotencia divina y la teoría de una ley natural inmutable. El dilema sería el siguiente: si el contenido de la ley pudiera ser conocido al margen de la revelación, Dios no sería absolutamente libre, ya que tal contenido debería ser inmutable; si el contenido de la ley no pudiera ser conocido al margen de la revelación, Dios sería absolutamente libre, pero ¿cuál sería la situación moral del hombre que no tuviera conocimiento de la revelación? Y Occam, al fin y al cabo un pensador

7 Entendemos por ley natural, las exigencias o prescripciones que dicta la razón de acuerdo con nuestra condición humana; espíritus encarnados, por tanto situados en su espacio y tiempo concretos y perfectibles en la medida de nuestra apertura al Absoluto. Para un estudio del concepto de ley natural véase Joseph de Finance, "La noción de ley natural", Revista de Filosofia UIA, No. 10, 1971. El autor parte del hecho indiscutible de la devaluación y desuso en que ha caído la expresión "Ley natural" para los filósofos contemporáneos, y propone su estudio y recuperación desde las premisas actuales de la ética. 
escolástico, se ve en la necesidad de acudir a la doctrina "tradicional" de la recta ratio, de la conciencia como norma subjetiva que obliga al hombre a hacer lo que de buena fe cree recto de acuerdo con una moral provisional pero no ya de acuerdo con la ley natural. Esta misma conciencia es la que, ante los ordenamientos y prohibiciones divinas, debe juzgar y tener la confianza de que nuestros actos agraden a Dios.

En Lutero ya no queda ese residuo tradicional que sirvió a Occam para "resolver" de alguna forma el dilema. No existe alternativa y, por lo tanto, no hay dilema. La opción es clara: el contenido debe ser una ética revelada. Tal vez, a fuerza de ser precisos, la buena fe y la confianza, necesarias para Occam, lo son también para Lutero, pero en el orden de la pura ética revelada: la fe, y sobre ello volveremos más adelante, es un acto de confianza absoluta ${ }^{8}$.

Pero Lutero va más allá que Occam - y en esto consiste su originalidad, para responder a la segunda pregunta- cuando agrega a esta ética la tesis de que el pecado original corrompe totalmente la naturaleza humana haciendo que toda obra que emane de ella sea mala:

"el pecado original es una corrupción tan profundamente mala de la naturaleza humana. que la razón no es capaz de reconocerlo, sino que es menester creer en su existencia según la revelación de las Sagradas Escrituras". 9

La pregunta que salta inmediatamente es: ¿por qué Dios rèvela órdenes y prohibiciones al hombre, si aun conociéndolas y obrando obrará mal? Y con la respuesta regresamos a la tesis inicial: para que reconozca la imposibilidad de obrar bien, desconfie de sí mismo y descubra la fuente de esa imposibilidad en el pecado original. Se cumple así una finalidad práctica.

El siguiente paso en la búsqueda de la felicidad y salvación del individuo, supuesta la conclusión anterior, lo expresa Lutero en dos textos significativos:

"Una vez que el hombre haya visto y reconocido por los manda-

"Sobre estas bases se comprende la tesis del "libre examen", es decir, la libre interpretación de las Sagradas Escrituras por la razón individual, bajo la pregunta y directa inspiración de Dios.

- Los Artículos de Esmalcalda, Tercera parte, El Pecado, Cfr. La liberrad (ristiana, Cap. VI. 
mientos su propia insuficiencia, le acometerá el temor pensando cómo satisfacer las exigencias de la ley, ya que es menester cumplirla so pena de condenación; y se sentirá humillado y aniquilado, sin hallar en su interior algo con qué poder justificarse". ${ }^{10}$

Ese estado existencial de reconocer la propia insuficiencia, la humillación y el vacío interior, despierta un estado de angustia dolorosa - tan bella y dramáticamente descrito por Kierkegaard- que desemboca en el arrepentimiento:

"Así se hace sentir el hacha tajante de Dios, hundiendo tanto a los pecadores notorios como a los falsos santos, aniquilándolos, despojándoles de toda razón e infundiéndoles espanto y angustia (...). Aquí no se trata de activa contritio, o sea, de un arrepentimiento artificial, sino de passiva contritio, esto es, del sincero dolor del corazón, del sufrir y sentir la muerte misma: así comienza el verdadero arrepentimiento"."

Lutero opone aquí la pasiva contritio - arrepentimiento del corazón- a la activa contritio - arrepentimiento de las obras realizadas - o moral de los "papistas", como la llama, que confian en Dios para el perdón de sus obras. La passiva contritio debe ser eficaz y para ello "debe dudarse firmemente de todo, de cuanto somos, pensamos y hacemos", sólo así el alma, en ese vacío existencial preparado por el reconocimiento de la insuficiencia y el arrepentimiento, queda plenamente "abierta", "absolutamente libre" y en "espera".

Llegados a este punto bien podemos pensar que el alma se halla en un abismo que la puede conducir a la nada, a la muerte de Dios y de toda religión, o al encuentro del mismo Absoluto por un acto de entrega y de confianza total:

"Entonces es cuando la otra Palabra, la promesa divina, se allega y dice: ¿Deseas cumplir los mandamientos y verte libre de la codicia malsana y del pecado como los mandamientos exigieren? ¡Cree en Cristo! ¡En El te prometo gracia, justificación, paz y libertad plenas! Si crees ya posees, mas si no crees nada tienes". ${ }^{12}$

10 La libertad cristiana, cap. IX.

11 Los Artículos de Esmalcalda, El arrepentimiento.

12 La libertad cristiana, cap. IX. La Palabra, dice Lutero, libera el alma -al hombre interior- haciéndola justa y libre. Deudor aqui de la escolástica tardía, opone el 
De esta manera, descansar en la Palabra, creer en Cristo es entregarse con una confianza absoluta a El. La fe para Lutero sería un acto volitivo de afirmación exigido por el reconocimiento de la insuficiencia y de la passiva contritio:

"Pues, cuando en su corazón advierte la confianza de que la obra agrada a Dios, entonces es buena aunque sea tan insignificante como levantar una paja (...) la fe sola convierte en buenas a todas las demás obras, las vuelve agradables y dignas por el hecho de que se confia en Dios y que no se duda de que ante él todo lo que el hombre hace está bien hecho"."13

Y así, el pesimismo inicial es superado por un optimismo fundado en la fe divina:

"Lo mismo un cristiano, que vive en confianza en Dios, sabe todas las cosas, es capaz de todo y emprende cuanto haya que realizar. Y todo lo lleva a cabo, alegre y libremente, y no con ánimo de acumular abundantes buenos méritos y obras. Más bien, es para él un placer el agradar a Dios de esta manera, y servir a Dios sinceramente y sin intención alguna; le basta con que a Dios le agrade". ${ }^{14}$

El recorrido que conduce al hombre a este estado, no implica en él, según Lutero, una actitud totalmente pasiva ante la misericordia divina, digamos, ante el auxilio - la gracia- que Dios brinda para ello. Más bien, la liberación del alma se logra por un esfuerzo de la voluntad para romper la atadura del cuerpo y del pecado. No resulta nada fuera de propósito preguntarse si, al fin y al cabo, este optimismo de Lutero como meta lograda en la fe no descansa sobre un optimismo en la voluntad firme del hombre para vencer las limitaciones y exigir la fe. Entonces, ante esta exigencia, ¿es posible hablar de la gracia como de una segunda naturalezi $\mathrm{J}$ de la fe como un don gratuito de Dios? Como dice Maritain, Lutero "venía a practicar aquel pelagianismo que echaba en cara a los católicos y del cual él

hombre interior al hombre exterior, el alma al cuerpo. Este, lejos de ser un auxilio es un estorbo, hace al alma más sierva y, así sólo la Palabra puede liberarla. Es evidente el dualismo platónico que animó a Lutero, coherente con su moral del corazón.

${ }_{13}$ Sermón sobre las buena obras. Primera parte, IV, Cfr. Salmo 130 V. 1-8 del que Lutero hace una exégesis atenta y profunda según sus principios.

14 Ibid. VI. 
nunca se verá libre"15 y que consiste en creer más en las propias fuerzas que en la gracia. ${ }^{16}$

La religión, entonces, más que una honra a Dios es el medio por el cual el hombre alcanza esa plenitud existencial que surge ante el vértigo de un alma que está a punto de sumergirse en la nada o en los brazos de Dios. ¿Puede acaso Dios negar la fe a un ser en tal estado? En otros términos, la religión es un esfuerzo de la voluntad por el que se quiere y se exige ardientemente la fe pero no ya la fe como don gratuito sino la "fe confianza".

Con todo, esta concepción luterana presenta una visión mutilada de la religión. No podemos olvidar que por más optimismo que queramos ver en Lutero éste parte de una naturaleza humana corrupta por el pecado original. Por lo tanto, toda actividad religiosa debe deshacerse de aquello que impida un acceso franco y directo a Dios, es decir, de cualquier acto externo y aun de todo acto interno que no sea ese esfuerzo de la voluntad por el que se busca ardientemente la fe.

Con Lutero se ha dado un paso decisivo en el proceso de naturalización de la religión y es el de haber eliminado la actividad cultural para reducir la religión a una forma de conciencia de Dios por vía volitiva. Sin embargo, el recurso a la fe. aun entendida como fe confianza, hace de la Teología - de una ética revelada - el fundamento de la religión. Tendremos que esperar al racionalismo para que la religión se desligue de todo vínculo teológico y al deísmo para que se rompa, en definitiva, con todo vínculo consciente de dios.

\section{Spinoza y el racionalismo}

Entre la muerte de Lutero y el nacimiento de Spinoza media casi un siglo. El protestantismo se consolida en varias partes (ie Europa y adquiere un impulso renovador con Juan Calvino,

15 Jacques Maritain, Tres refommadores. Ed. Difusión. 1968. p. 14

16 La doctrina luterana deja las pucrtas abiertas a dos posibles interpretaciones: la liberal, que ofrece una interpretación puramente natural de la religión, contraponiéndola a la vida sobrenatural - rechazada o ignorada - que se une aqui a toda la corriente racionalista y deísta que, tras pasar por la ilustración, llega hasta Kant como sistematizador y se prolonga a través de Hegel hasta el siglo XX con R. Bultmann y todo el proceso de desmitologización, por ejemple; o la ortodoxa. que desde una posición existencial trata de salvar lo natural oponiendo, radicalmente. lo finito a lo infinito, lo temporal a lo eterno, dando lugar a lo que se ha llamado la "teologia dialéctica", que desde Kierkegaard halla su expresión más plena en K. Barth. 
mientras dos pensadores contemporáneos establecen las nuevas bases del pensar filosófico, René Descartes y Thomas Hobbes. El nuevo pensar nace bajo un clima de incertidumbre. Las tesis protestantes dejaron las puertas abiertas a un posible escepticismo fundado en el rechazo a la razón y la afirmación de la voluntad, así como el desprecio por la tradición y la autoridad suplantada por la tesis del libre examen. Si bien al principio, sobre todo con la influencia directa de Lutero y Calvino, se puede pensar en un protestantismo ortodoxo, poco a poco el contacto con el racionalismo y el deísmo inglés hace olvidar ese espíritu humanista de los fundadores para exaltar y desarrollar las tesis más acordes con el espíritu liberal de la época.

De todos los racionalistas es Spinoza quien lleva a sus últimas consecuencias las tesis de esta doctrina bajo la influencia de Descartes, y el que establece bajo la guía del deísmo inglés de Cherbury y Hobbes los principios para una filosofía de la religión natural.

Al igual que la de Lutero, la filosofía de Spinoza es esencialmente práctica. Su interés es el de conducir al hombre a la felicidad absoluta, a un "gozo eterno y a una alegría suprema y contínua" 17 porque:

"El amor por una cosa eterna e infinita alimenta el alma de pura alegría y la libra de toda tristeza; lo que es muy de desear y digno de ser buscado con todas nuestras fuerzas". ${ }^{18}$

Pero es claro que una cosa es el amor por algo eterno e infinito y otra cosa es decir que lo eterno e infinito existe. Por ello, antes de preguntarse por la esencia del Absoluto. Spinoza debe demostrar su existencia.

$\mathrm{El}$ bien y el mal, afirma, se dice de forma relativa al conocimiento humano, al igual que lo perfecto y lo imperfecto. lo justo y lo injusto, porque ninguna cosa considerada en su esencia puede llamarse perfecta o imperfecta, pues todo lo que ocurre se cumple según el orden eterno y las leyes determinadas de la Naturaleza. Sin embargo, es evidente que el hombre es impotente para poder abarcar con su pensamiento ese orden, $y$ ante tal espectáculo "el hombre imagina una condición humana

\footnotetext{
17 Tratade sobre la reforma del entendimiento, Bajel, Buenos Ai. 1944. No. 1.
}

18 Ibid, No. 10 
mucho más poderosa que la propia y como no ve obstáculo para adquirirla se siente incitado a buscar los medios que le conduzcan a tal perfección". ${ }^{19}$ La conciencia de la finitud humana ante un orden que le sobrepasa despierta una tendencia infinita que, a menos de considerarla absurda, debe recaer sobre algo Absoluto. Y este Absoluto entendido como el goce de la perfección - si fuera posible con otros individuos - consiste en "el conocimiento de la unión del espíritu con toda la Naturaleza". ${ }^{20}$

Para emprender esta tarea colosal de unir el espíritu con toda la Naturaleza son necesarias tres condiciones:

1. Tener un conocimiento suficiente de la Naturaleza $-\mathrm{y}$ nada más adecuado para ello que la Ciencia- para adquirir el gozo de la perfección y poder formar una sociedad tal como sería de desear, para que el mayor nú mero llegue, tan fácil y seguramente como sea posible, a esa meta. ${ }^{21}$

2. Buscar un método para curar el entendimiento y, hasta donde sea posible, al comienzo, purificarlo para que entienda las cosas fácilmente, sin error y de la mejor manera. ${ }^{22}$ De los cuatro modos de conocer que existen - de oídas, por experiencia vaga, por inferencia inductiva o por esencia- el mejor para alcanzar la meta es el de la esencia o intuitivo que nos da claridad y distinción y cuyo modelo perfecto es el matemático. Además, el conocimiento de la esencia nos lleva de la mano a la existencia, pues la existencia singular de una cosa sólo es conocida si se conoce su esencia.

3. Sentar una moral provisional mientras alcanzamos el fin supremo, cuyos principios no deben emanar de la naturaleza sino de una convención. ${ }^{23}$

Ahora se entiende, una vez señaladas estas condiciones, que el método podrá aplicarse de manera adecuada cuando se tenga la idea clara y distinta del Ser perfectísimo, conocido por intuición. Y de su Esencia, por deducción rigurosa, según orden geométrico, se seguirá la existencia de todas las cosas. Es de advertirse, sin embargo, que Spinoza nunca pensó que cualquier hombre pudiera tener acceso a tal intuición de la esencia divina;

14 Ibid, No. 13

21) Ibid.

${ }^{21}$ Ibid., No. 14.

$2 z$ Ibid., No. 16 .

${ }^{23}$ Ibid., No. 17. 
si así fuera, en vano hubiera recomendado un pret. „ndo sunocimiento de la Naturaleza por la Ciencia, de un método y de una moral provisional. Más bien hay que entender que al escribir su Etica, Spinoza ya no se halla colocado deśie el ángulo de ascenso hacia la idea clara y distinta de Dios, sino desde la misma perspectiva de Dios y como sucede con estos filósofos que miran todas las cosas desde el punto de vista divino, todo se le presenta en un instante eterno. La línea que va de Plotino a Spinoza que pasa por Escoto Erígena y llega a Hegel, es la misma: un panteísmo que, en términos de Sciascia, llamaríamos "a-cósmico". Este panteísmo es el que animará todo el libro de la Etica y será el telón de fondo que no perderemos de vista al tratar el tema de la religión.

En el libro IV de la Etica Spinoza nos da una primera aproximación a la idea de religión distinguiéndola de la idea de moralidad:

"todo aquello que deseamos y hacemos y de lo que somos causa en cuanto tenemos idea de Dios o en cuanto conocemos a Dios lo refiero a la religión. Pero el deseo de hacer el bien que nace del hecho de vivir según la guía de la razón, lo llamo moralidad".:4

A partir de estas definiciones cabe preguntarse si en el sistema spinoziano hay entrada para una distinción esencial entre religión y moralidad si, como hemos visto, el obrar conforme a la idea de Dios, que es la misma Naturaleza y la misma Conciencia, es obrar según la guía de la razón, que es parte de la Conciencia universal. La distinción podría hallarse en la diferencia que existe entre la Conciencia universal y esta misma Conciencia en cada conciencia singular. Vivir de acuerdo con la primera sería vivir religiosamente; vivir de acuerdo con la segunda lo sería moralmente. Sin embargo, no es suficiente todavía el criterio de la conciencia para distinguir religión de moralidad, pues a mbas se inscriben en el ámbito del comportamiento sorial del hombre y éste se halla ligado al Estado.

Piensa Spinoza que para que los hombres puedan vivir en concordia y ayudarse es necesario que renuncien al ejercicio de su derecho natural y se den mutuamente la seguridad de que no obrarán nada que pueda redundar en perjucio ajeno. En el XXXVII.

24 Fitica, Fondo de Cultura Económica, México, 1958, libro IV, proposición 
estado natural no se da nada que sea bueno o malo por el consenso de todos, porque en el estado natural se mira y se obedece sólo a uno mismo, pero no sucede así en el estado civil, donde por consenso se dice lo que es bueno y lo que es malo y donde cada cual está obligado a obedecer al Estado.

Con este antecedente se entiende que vivir de acuerdo con la conciencia singular, que es vivir moralmente, sólo se hace en el estado civil, porque la moralidad surge después del contrato y por consenso. Pero vivir religiosamente - según la religión interior y no la exterior, que se hallará igualmente regulada por el Estado, como veremos en seguida - no supone contrato y, por lo tanto, tampoco necesita consenso. La religión, entonces, es propia del hombre natural mientras la moral lo es del hombre civil, porque el hombre que se guía por la razón es más libre en el Estado donde vive según el decreto común que en la sociedad donde sólo obedece a él mismo. El estado religioso sería una fase esclavizadora del hombre, que debe superarse bajo la guía de la razón en el Estado y que de esta forma sería la fuente de libertad para el individuo.

En el Tratado Teológico-político Spinoza vuelve sobre la relación entre religión y Estado partiendo ahora de la definición de ley y de la distinción entre ley humana y ley divina. Define la ley como "una regla de conducta que el hombre se impone e impone a otros con un fin determinado", y puesto que la ley depende de una necesidad natural "impone una manera de obrar fija y determinada". Por su parte, la ley humana se define como "la regla de conducta que sirve a la seguridad de la vida y sólo mira al Estado"; y la ley divina como aquella "que tiene relación con el bien supremo, con el verdadero conocimiento y amor de Dios" Esta ley divina, agrega:

“... es universal, no se apoya en la fe de los relatos históricos, pues el amor de Dios nace de su conocimiento y recibimos este conocimiento de las nociones universales que se revelan por sí mismas y llevan en sí una certidumbre inmediata, no exige ceremonias y el premio es esta misma ley". ${ }^{25}$

La ley humana responde a un fin utilitario y aparece sólo con el Estado; la ley divina, que no implica preceptos de orden sobrenatural, no guarda relación con el Estado y por ello

25 Tratado teológico-politico. Vd. Tecnos, Madrid. 1966. Cap. IV. 
es una exigencia universal de la razón. Por otra parte, las mismas Escrituras "enseñan que la inteligencia es la dicha y felicidad del hombre" y que:

"la sabiduría, es decir, la inteligencia, únicamente nos enseña a temer a Dios racionalmente, o sea, a darle culto verdaderamente religioso". 26

Puesto que "la sabiduría mana de la boca de Dios", nuestra ciencia y nuestro entendimiento dependen de la idea o conocimiento de Dios en lo que, a fin de cuentas, constituye nuestra felicidad. Además, "sólo después de haber conocido la naturaleza de las cosas y gustado las excelencias de la ciencia es posible fijar las bases de la moral y comprender la verdadera virtud". De ahí que:

"la dicha y tranquilidad del hombre entregado a la lectura de la inteligencia natural consiste más que en la fortuna (socorro externo de Dios), en su virtud interior (socorro interno de Dios), ya que por la vigilancia, la acción y el buen consejo se llega sobre todo a conservarlos".27

De lo dicho se desprenden dos conclusiones:

1. El verdadero culto religioso es temer a Dios racionalmente;

2. La religión es una virtud interior por la cual la inteligencia rinde "culto" a la naturaleza.

Ahora bien, si la religión es una virtud interior, ¿qué papel juega el Estado con respecto a ella? Y la respuesta es clara:

“...el culto de la religión y el ejercicio de la piedad deben acomodarse a la paz y a la utilidad de la república y ser determinados únicamente por los poderes soberanos, que de este modo se convierten en intérpretes suyos. Hablo expresamente del ejercicio de la piedad y del culto externo de la aeligión, no de la piedad misma y del culto interno, o sea, los medios con los cuales se dispone interiormente del espíritu para adorar a Dios en la interioridad de la conciencia. El culto interno de Dios y la piedad

26 Ibid. 
misma son un derecho de cada uno... que no puede depositarse en otro", 28

El Pontífice o la Institución no debe nunca interpretar la religión como culto interior, aunque sí tiene el deber de hacerlo con respecto al culto externo. Los derechos de la conciencia son inalienables y cada uno puede profesar el culto que mejor le parezca de acuerdo con una actitud de tolerancia. ${ }^{29}$

Una cosa resulta obvia si partimos de esta concepción, y es que destruído el Estado, la religión de un pueblo no puecie mantenerse como propia de una nación sola, sino "como enseñanza universal de la razón". 30 El Estado, entonces, presagiando a Hegel, se convierte en la norma de conducta para el hombre, y aquello que redunda en su conservación es justo, de lo contrario es injusto:

"De esto resulta que nada piadoso puede hacerse con el prójimo que no sea impío, si de ello resulta daño para la república; $y$, por el contrario, que nada impío puede hacerce con el que no sea hijo de la piedad si se hizo por la conservación del Estado (...) Nadie puede obedecer a Dios rectamente si no acomoda a la utilidad pública el culto y la piedad a que está obligado y, por consiguiente, si no obedece todos los decretos del soberano (...) Todo el misterio sagrado y el ejercicio de la religión depende únicamente del mandato de los soberanos". 31

Bastan estas ideas para encontrar en Spinoza todas las bases para una religión natural o de la razón. La religión no sólo ha roto todo vínculo con la Teología, sino que incluso es difícil pensar en una fundamentación ontológica estricta: la religión no implica ya el culto a un Ser trascendente y real, personal, y "santo" según la feliz denominación de Otto. Tanto el panteísmo como el deísmo, bien sea resaltando la inmanencia a costa de la trascendencia o viceversa, privan a la religión de una auténtica fundamentación. A tal punto que la religión pierde su objeto propio para convertirse en un culto que se define como

28 Ibid, cap. XIX.

${ }^{24}$ Sobre la idea de tolerancia véase infra. Nota 40.

30) Tratado teológico-politico, cap. XIX. Los ecos de esta doctrina encontrarán su fundamentación en uno de los libros poco leídos de Kant, pero imprescindible para la comprensión cabal de su pensamiento, La religión en los limites de la pura razón.

"Ibid. 
"temor racional", o bien como algo supersticioso y primitivo que debe ceder paso a la moralildad. Dios existe más como una garantía de nuestra racionalidad moral que como término de un culto exigido en justicia. El culto a Dios se ha convertido en un culto a la Razón. Además, si esta Razón, como piensa Spinoza, cumple sus exigencias más plenas en el Estado, nada impide convertir la religión en un culto al Estado, y no sólo en lo que se refiere al culto exterior sino también al culto interior por más esfuerzos que haga Spinoza para rescatar los derechos de la conciencia. Porque al fin, si éstos no se fundan en una ley natural, porque entre otras cosas tal conciencia se sitúa en una sociedad irreal en la que por definición no existe lo justo o lo injusto, lo bueno y lo malo, y que debe superarse para dejar paso al hombre civilizado, todos los esfuerzos no pasan de ser una buena intención pero carentes de justificación.

Con los antecedentes racionalistas y el protestantismo difundido y en gran parte asimilado en Europa, el clima se presentaba favorable para una labor de síntesis y sistematización de ambas corrientes. La tarea estuvo a cargo de Pierre Bayle, cuyo pensamiento, como veremos, influyó decisivamente el: todo el S. XVIII.

\section{Bayle y el escepticismo ateo}

Al estudiar el pensamiento de Bayle se tiene la impresión de asistir a un cierto escepticismo "heróico" que, cargado de una fina ironía y de una exagerada erudición e irrespetuosidad, se levanta contra todo dogmatismo racional, histórico y religioso:

Ese escepticismo, nos dice B. Magnino, nace en nombre de la tolerancia y acaso un poco por la fatiga de unas luchas que acaban por alejar al hombre de la vida y de sus acuciantes problemas: ello implica desconfianza en el pensar, en la historia y en el patrimonio cultural del tiempo periclitado, implica deseo y ansia de algo nuevo, de libertades jamás gozadas, de experiencias lozanas y dignas, empero, de existir, en tanto que indispensables para la concepción de la vida que anima al nuevo siglo ". ${ }^{32}$

$\mathrm{Y}$, ciertamente, Bayle será el heraldo de un nuevo siglo

" Bianca Magnino, Iluminismo y cristianismo. T. Il. Francia. Ed. Litúrgica Español, 1962. p. 26. 
- La Ilustración- que en mayor o menor grado, consciente o no, sigue ejerciendo en el hombre moderno un atractivo especial.

Su vida podría servir de testimonio para comprender el espiritu de la época, pero lo más importante es que su fïlosofía se hallat justo en la encrucijada de los dos movimientos más significativos del momento: el protestantismo y el racionalismo, que en sus líneas generales hemos visto anteriormente.

Desconocer la infuencia del protestantismo y el racionalismo sería dejar una gran laguna, ya que a través de esas fuentes y en una sintesis formidable Bayle se ve conducido inevitablemente al escepticismo: en primer lugar, como ya mencionamos, rechazando todo dogmatismo histórico y religioso, invalidando la tradición y la autoridad, punto que comparten igualmente el protestantismo - al menos negando la autoridad de la iglesia y su tradición con la tesis del libre examen- y el racionalismo; en segundo lugar, y como consecuencia necesaria del anterior, negando la revelación y la fe, juzgados por el tribunal de la razón (racionalismo), pero de una razón limitada y manchada por el pecado original (protestantismo); y en tercer lugar, como conclusión, reduciendo la religión a una cuestión de opinión, todas igualmente verdaderas que deben conducir al hombre a una actitud de tolerancia más que de dogmatismo.

Trataremos de seguir este orden señalando, donde sea necesario, algunas de las ideas que se desprenden de los puntos anteriores y que son, principalmente, la posibiidad de un ateísmo moralmente bueno, mejor incluso, como actitud, que la idolatría - lo que supone una radical separación entre moral y religióny la idea muy querida de los ilustrados de que el miedo y la ignorancia son el origen de la religión.

El racionalismo regulado por el principio de inmanencia, condujo a Bayle, inevitablemente, a dos cosas: a una actitud antihistórica, ya que los hechos se sientan sobre testimonios imposibles de ser juzgados críticamente por la razón pues, además de ser mudables, son valorados apasionadamente por el historiador; y a una incredulidad de lo maravilloso, lo extraordinario. Para Bayle, "la credulidad humana se basa en el respeto ciego por la autoridad de la tradición", que viene dada por "leyendas de poetas, testimonio de historiadores y argumentaciones de filósofos", ${ }^{33}$ que más que fómentar el juicio crítico es la causante de una extremada propensión a temores irracionales y

33 Ibid. p. 30 y ss. 
de un clima de gran inseguridad, propicios ambos para el surgimiento de la religión, yue en estos términos no sería más que superstición e idolatría. ${ }^{i+}$ De esta manera la tradición se definiría como "la atirmación de dos o tres personas, tras haber sido repetida por el conjunto innumerable de las personas crédulas", que no son sino "espíritus vulgares que se comportan como borregos abandonándose a la buena fe de los demás". Contra esta actitud es necesario oponer una crítica racional que nos ofrezca seguridad y progreso ininterrumpido. El oscurantismo pagano y medieval debe ceder paso a la era de la luz, y así "el testimonio de un hombre no debe tener más fuerza que la proporción del grado de certeza que él ha adquirido instruyéndose plenamente del hecho".

Es claro que estas ideas no podían chocar con la tesis protestante del libre examen que suponía la exaltación de la conciencia contra cualquier tradición y autoridad, especialmente la tradición sagrada de la Iglesia. Al igual que la tradición profana o pagana debió sujetarse a la crítica racional, de igual manera tendrá que suceder con las Sagradas Escrituras, y con ellas el milagro, las profecías, etc. ¿Acaso no hay deficiencias on las traducciones de los Textos, transposición de versicilos y narraciones fuera de lo común?: "En cualquier historiador tales. omisiones harían dudar de la buena fe del historiador, ¿por qué no lo mismo con las Sagradas Escrituras?". Es necesario, wnonces, despojar a las Escrituras de fantasías y mitos. Despmes de esta purificación es evidente que la Iglesia no puede ser consiclerada ya como la autoridad depositaria de la tradición divina y la intérprete de los libros Sagrados; incluso, como es natural, ta fe misma es cuestionada:

"Estáis acostumbrado, por vuestro carácter de teólogo, a no razonar mucho, dado que creéis que existe el misterio, lo cual supone una docilidad loable, pero muchas veces, por el excesivo crédito que se le da, no deja de violar los derechos de la razón.", 35

En síntesis, la tradición y la autoridad pagana puestas en duda por el juicio a-histórico del racionalismo, se une al

34 Véase Tomás Alvira, Pierre Bayle. Pensamientos diversos sobre el cometa. M.E.S.A. col. "Crítica Filosófica", Madrid, 1978, p. 37 y ss. El autor presenta una buena selección de textos de los Pensamientos con comentarios críticos a los mismos.

35 Apud Tomás Alvira, op. cit., p. 44. 
rechazo de la tradición sagrada por el libre examen. La fe deberá sujetarse al tribunal de la razón, pero ¿es posible hacer la exaltación de la razón desde el supuesto de una naturaleza corrupta?

En la línea racionalista Bayle se ve en la necesidad de otorgar un valor absoluto al entendimiento:

"Cualquier dogma que no quede homologado, por así decir, a la vez que verificado y registrado por el veredicto de la razón y la luz. natural no puede ser sino vacilante y frágil como el vidrio". ${ }^{36}$

En la línea protestante se ve obligado a destacar su debilidad y exaltar el valor de la conciencia:

"La razón humana es demasiado débil para esto; es un principio de destrucción y no de edificación... La razón no es propia sino para hacer conocer al hombre sus tinieblas y su importancia, y la necesidad de otra revelación (además de la revelación natural de la razón). Esta es la de las Escrituras".,37

"Para establecer este principio, es necesario tener en cuenta: que en materia de religión la regla para juzgar no está en el entendimiento sino en la conciencia; es decir. que no hay que tomar los objetos según las ideas claras y distintas, adquiridas por un examen severo, sino según que la conciencia nos dicte tomarlas como agradables a Dios". 38

La contradicción de estos textos es sólo aparente. Podría caber, tal vez, en un protestantismo ortodoxo como el de Lutero, pero Bayle va más lejos. La fe no es ya un acto de confianza o de afirmación volitiva -esto, al fin, supone la veracidad de la revelación cuyo garante es la misma autoridad divina-, sino tan sólo un acto moral que, al no implicar conocimiento perfecto, se reduce a una simple opinión y como tal muy vacilante, que poco o nada tiene que ver con el actuar del hombre. Para Bayle como bien señala Magnino, la cuestión de derecho no está en decidir qué doctrina está contenida en las Sagradas Escrituras, sino en saber "si es verdadero todo lo que Dios ha revelado", ${ }^{39}$ y para ello es necesario sujetar la Palabra al

${ }^{36}$ Apud Magnino, op. cit. pp. 42-43.

37 Apud Sandberg, At the crossroads of faith and reason. An Essag' on Pierre Bayle The University of Arizona Press, Tucson, 1966, p. 4.

${ }^{38} \mathrm{Ibid}$, p. 65

${ }^{39}$ Magnino, op. cit, p. 29 nota 2. 
tribunal de la razón pero no ya como una "enseñanza universal de la razón" - conclusión a la que llegaba Spinoza una vez. destruido el Estado y a la que volverá Kant para escapar del más crudo escepticismo-, sino de una razón individualizada muy débil y falible, pero con el importante papel de desmitologizar las Escrituras a través del libre examen que, como hemos visto, conduce a la negación de toda autoridad depositada en la Iglesia. No es de extrañarse que, bajo la influencia racionalista, Bayle dé un paso más y dude hasta de la misma autoridad divina para exaltar el valor de la conciencia personal.

Pero de ser así, ¿qué señal tenemos de que existe una religión verdadera revelada? Ninguna. Al negar el valor de la revelación, toda religión, que es cuestión de conciencia y opirión, posee el mismo valor que otra y todas son verdaderas. Además, sería un atentado contra la verdad querer forzar a la conciencia humana a aceptar una religión como la verdadera: esto violaría los derechos a la conciencia y provocaría una situación de intolerancia tan cara a la sociedad. En nombre de los derechos de la conciencia hay que pregonar la tolerancia. ${ }^{40}$

4) La noción de tolerancia, tal como la entiende Bayle, descansa sobre un supuesto especulativo: la verdad es algo absolutamente inalcanzable para la inteligencia humana. Ser tolerantes, entonces, es la actitud que se sigue cuando se comprende que todos los hombres tienen derecho a sostener lo que les parezca más conveniente, pero con la condición de que no consideren que su opinión es la verdadera, lo que llevaria a condenar el resto de las opiniones como falsas. Por el contrario, pensamos que la verdad es alcanzable por la inteligencia humana y que tal verdad es absoluta, es decir, independiente del tiempo y del lugar en los que se formule. Pero distinguimos verdad absoluta de verdad exhaustiva porque "La verdad no consiste en conocer el todo de un algo sino más bien en conocer algo de un todo". Los escolásticos distinguían entre conocimiento adecuado (exhaustivo) y conocimiento objetivo (parcial pero absoluto) de una cosa. En tanto seres contingentes nos es imposible alcanzar la verdad exhaustiva pero podemos llegar a verdades parciales con carácter absoluto. Precisamente, esa imposibilidad es la condición necesaria para un progreso en la verdad: pero no a base de opiniones sino de demostraciones rigurosas. Verdad y tolerancia, entonces, son compatibles, en tanto la ségunda se funda en la posibilidad que tiene el ser humano de conocer progresivamente la verdad y no bajo el supuesto de que ésta es inalcanzable por la inteligencia humana. Con respecto a la religión pensamos que no es una cuestión de opinión sino de estricta fundamentación racional en las órdenes ontológico, gnoseológico y moral. Por lo tanto, desde este punto de vista, sí es posible hablar de verdadera ofalsa religión. Si lo anterior se comprende, es fácil ver que el problema no consiste en cuestionar si se deben o no se deben salvar los derechos de la conciencia a profesar un culto determinado; éstos siempre deben defenderse en tanto son los derechos de una persona, pero otra cosa muy distinta es tolerar el error o la falsedad. Se puede y se debe ser tolerante con la persona pero no con los errores o las falsedades que, como tales, carecen de derechos. "Tan temible, expresa Ruiz de Santiago, es la pretensión del conocimiento de una verdad exhaustiva y excluyente de cualquier otra, como la práctica de una tolerancia, fundada dogmáticamente en el escepticismo" ESTUDIOS 2, ITAM, primavera 1985, pp. 75-76. 
Si al negar la tradición y la autoridad Bayle parece caer en una postura fideista, ahora dudando de la misma autoridad divina y reduciendo la fe a simple opinión para sostener una religión natural, el fideísmo cede su lugar al deísmo. Pero del deísmo más exagerado al ateísmo hay sólo un paso, pues a fuerza de hacer incomprensible la esencia divina para la razón es natural que todo lo que ésta puede decir sobre Dios sea erróneo. La razón se vería conducida más a la superstición e idolatría que al culto verdadero, y entre conocer y querer mal a Dios idolatría-o ignorarlo - ateísmo-, nadie podrá negar que sea preferible lo segundo, pues todo mundo prefiere ser ignorado a ser mal querido, y Dios no es aquí la excepción. El ateo a los ojos de Dios es mejor que el idólatra, y no sólo desde un punto de vista gnoseológico sino sobre todo, moral.

Para Bayle la religión se entiende como un conocimiento de Dios, y como conocimiento nada tiene que ver con la conducta moral del hombre: ¿no son acaso los mismos demonios que conocen la existencia de Dios los príncipes del mal y no es evidente en muchas personas viciosas que el conocimiento que tiene de Dios poco o nada les ayuda para la corrección de sus inclinaciones?: 41

"Cuando el corazón ha sido poseído una vez por un amor ilegítimo; cuando no se quiere satisfacer más que ese amor... no hay luz de la conciencia que sea capaz de regir, no se consulta más que a la pasión y se juzga sobre lo que hay que hacer aquí y ahora contra la idea general que se tiene del deber". ${ }^{42}$

Pero no sólo la religión es moralmente ineficaz. Si seguimos al espíritu protestante, vemos que la fe misma nada tiene que ver con las obras, pues si entre los que creen hay tantos que obran mal ¿de qué sirve la fe? En estas condiciones, el que ignora a Dios -el ateo o el pagano, que para Bayle son sinónimos-y el cristiano se hallan a la misma altura con respecto a la conducta moralmente recta. Pero ¿qué decir de algunas personas

4 Véase ésta y otras pruebas como argumentos para separar moral y religión en Tomás Alvira, op. cit. p. 109 y ss.

42 A pud Ibid. p. 106. El mismo autor hace suya una aclaración de C. Fabro, que conviene tener presente y es la de que Bayle al separar mora! y religión eleva a una cuestión de derecho algo que no es sino una cuestión de hecho, pues la religión y la conducta pueden de hecho separarse en cuanto el hombre es libre de obrar en contra de sus creencias religiosas, pero esto no quiere decir que se separen de derecho. 
que obrando de acuerdo con el conocimiento que tienen de Dios son mejores que otros que no lo tienen? El caivinismo de Bayle nos ofrece la respuesta: se hallan predestinadas. ${ }^{43}$ De esta manera, entre el predestinado y el ateo no existe término medio.

Ahora bien, lejos de que el ateísmo nos conduzca a la desesperación y a la angustia - por el desconocimiento de la revelación y de Dios-, como podía suceder en un protestantismo ortodoxo, la originalidad de Bayle estriba, precisamente, en justificar el ateísmo como una actitud moralmente positiva que no necesariamente debe conducir a la corrupción de las costumbres o la moral y, mucho menos, a la desesperación. Al negar toda validez a la religión y a la fe en el actuar humano la misma moralidad se pone en tela de juicio, ya que no es admisible una ley natural como participación de la ley divina, no hay otra norma o criterio válido universal sino un claro escepticismo moral y, como es natural, carece de sentido cuestionar acerca del arrepentimiento de un acto cuando la misma libertad está puesta en duda y no es posible ya sentirse culpable ante alguien que es incognoscible.

En síntesis, la ignorancia de Dios que en Bayle no supone un rechazo voluntario, susceptible de considerarse como falta moral en tanto viola el orden natural de la criatura al Creador, nada tiene que ver con la moralidad. El hombre puede sentirse libre de culpa ya que la ignorancia que tiene de Dios no es una ignorancia culpable, pues la distancia que existe entre la esencia incomprensible de Dios y su naturaleza corrupta es insalvable, a menos que prefiera caer en el vicio de la idolatría. El ateo, entonces, puede ser un hombre honrado, libre de toda superstición e idolatría y, además, apto para formar una sociedad justa. Esto lo ve claro Marx cuando afirma en La Sagrada Familia:

"Bayle fue el primero que anunció la sociedad atea que se preparaba, demostrando que puede existir una sociedad de puros ateos, que un ateo podía ser un hombre honesto, que el hombre no se corrompía por el ateísmo, sino por la superstición e idolatría". 44

Después de todo lo dicho, no es de extrañarse que el pensamiento de Bayle haya sido muy del agrado de los ilus-

${ }_{43}^{43}$ Cfr. Ibid., p. 120

${ }^{44}$ Apud. Ibid., p. 130 
trados. El escepticismo al que irremediablemente conduce su doctrina, que se traduce en una posición atea en materia de religión que lejos de ser censurable se justifica como moralmente buena, tranquilizará la conciencia de muchos hombres del siglo XVIII que, bajo el lema del progreso y de la tolerancia, encontrarán un obstáculo en la religión y en la fe.

Con Bayle, el proceso de naturalización llega hasta sus últimas consecuencias: la afirmación del ateísmo para privar a la religión, en definitiva, de toda fundamentación. Sin fundamentación teológica o metafísica y sin objeto propio - el culto debido a Dios-, la religión termina por confundirse con la moral. Una moral que ya no requiere de un Ser trascendente y cuyos principios deben ser a la par generales y útiles para el género humano. La búsqueda de esos principios será una de las tareas que ocupará a los ilustrados desde Voltaire y Hume hasta Kant. 